\title{
Rise in frequency of surface melting at Siple Dome through the Holocene: Evidence for increasing marine influence on the climate of West Antarctica
}

\begin{abstract}
Sarah B. Das ${ }^{1,2}$ and Richard B. Alley ${ }^{1}$
Received 6 April 2007; revised 8 September 2007; accepted 16 October 2007; published 29 January 2008.

[1] A new melt layer history from Siple Dome, West Antarctica, indicates notable lateHolocene summertime warming. Visual stratigraphic analyses of the 1004-m ice core identified 62 years with melt layers. Melting events began around $11.7 \mathrm{ka}$, followed by a period of no melting from 8.8-6.6 ka. Melt layer frequency increased from 6.6 ka to the present, with the 1000-year-average melt layer frequency reaching a maximum of $2 \%$ at $0.8 \mathrm{ka}$. We use our millennial-scale archive of melt events as a unique seasonal paleothermometer to elucidate changes in West Antarctic Holocene summer climate. Our calibration suggests the change in melt frequency from $0 \%$ to $2 \%$ may represent a summer temperature increase of $\geq 2^{\circ} \mathrm{C}$ from the middle to late Holocene. This temperature change cannot be explained entirely by local change in ice elevation or summer insolation and is in contrast to East Antarctic climate records, which show peak warmth in the early Holocene followed by stable or decreasing temperature. We interpret the rise in melt frequency as evidence of an increasing marine influence on the Ross Sea sector of West Antarctica. Although the surface elevation of Siple Dome has not changed greatly, the continued lateral retreat of the West Antarctic ice sheet from its Last Glacial Maximum configuration (across the outer continental shelf), and the delayed drawdown in ice thickness from the adjacent coastal Marie Byrd Land region, in conjunction with periods of increased cyclogenesis, perhaps related to variations in ENSO, would allow a moderated maritime climate to more easily reach West Antarctica.
\end{abstract}

Citation: Das, S. B., and R. B. Alley (2008), Rise in frequency of surface melting at Siple Dome through the Holocene: Evidence for increasing marine influence on the climate of West Antarctica, J. Geophys. Res., 113, D02112, doi:10.1029/2007JD008790.

\section{Introduction}

[2] The Antarctic Ice Sheet experiences very little surface melting because of consistently low air temperatures throughout the summer, except on and near the marginal ice shelves and in the Antarctic Peninsula. Mass loss from Antarctica is primarily through calving of icebergs from ice shelves and melting under the ice shelves, and to a lesser extent from sublimation and meltwater runoff from the surface. Across most of the interior of Antarctica, any melting that occurs tends to be isolated and in response to anomalously high air temperatures [Das and Alley, 2005].

[3] To date, surface melting across Antarctica is monitored primarily through satellite observations. Most valuable are $\sim 25$ years of passive microwave records, which provide daily brightness temperatures from the surface of the ice sheet that are highly sensitive to the onset of melting

\footnotetext{
${ }^{1}$ Department of Geosciences and Environment Institute, Pennsylvania State University, University Park, Pennsylvania, USA.

${ }^{2}$ Now at Department of Geology and Geophysics, Woods Hole Oceanographic Institution, Woods Hole, Massachusetts, USA.
}

Copyright 2008 by the American Geophysical Union. 0148-0227/08/2007JD008790\$09.00 [e.g., Zwally and Fiegles, 1994; Fahnestock et al., 2002; Torinesi et al., 2003; Liu et al., 2006]. Because of the rarity of melt events, the large interannual variations in extent, and the short length of the satellite time series (1978-present), spatial and temporal trends of melt in Antarctica are not statistically significant [Liu et al., 2006]. At the same time, a strong correlation between melt events and elevated air temperature (as was found by Liu et al. [2006]) demonstrates that variation in melt could serve as a diagnostic indicator for regional temperature change, especially on longer timescales, if records of past melt are available [Das and Alley, 2005].

[4] Previous studies have used melt layers in Arctic ice cores to infer Holocene summer climate variability in Greenland [Herron et al., 1981; Langway and Shojii, 1990; Alley and Anandakrishnan, 1995; Kameda et al., 1995; Rowe et al., 1995], on the Agassiz Ice Cap [Fisher et al., 1995], and on the Devon Ice Cap [Koerner, 1977]. These Arctic studies have demonstrated the utility of records of both individual melt layers and amount-meltpercent in ice cores for reconstruction of climate variability and change. For example, both the Agassiz and Greenland Summit (GISP2) studies found extensive melting during the early to middle Holocene, with melt amounts generally 


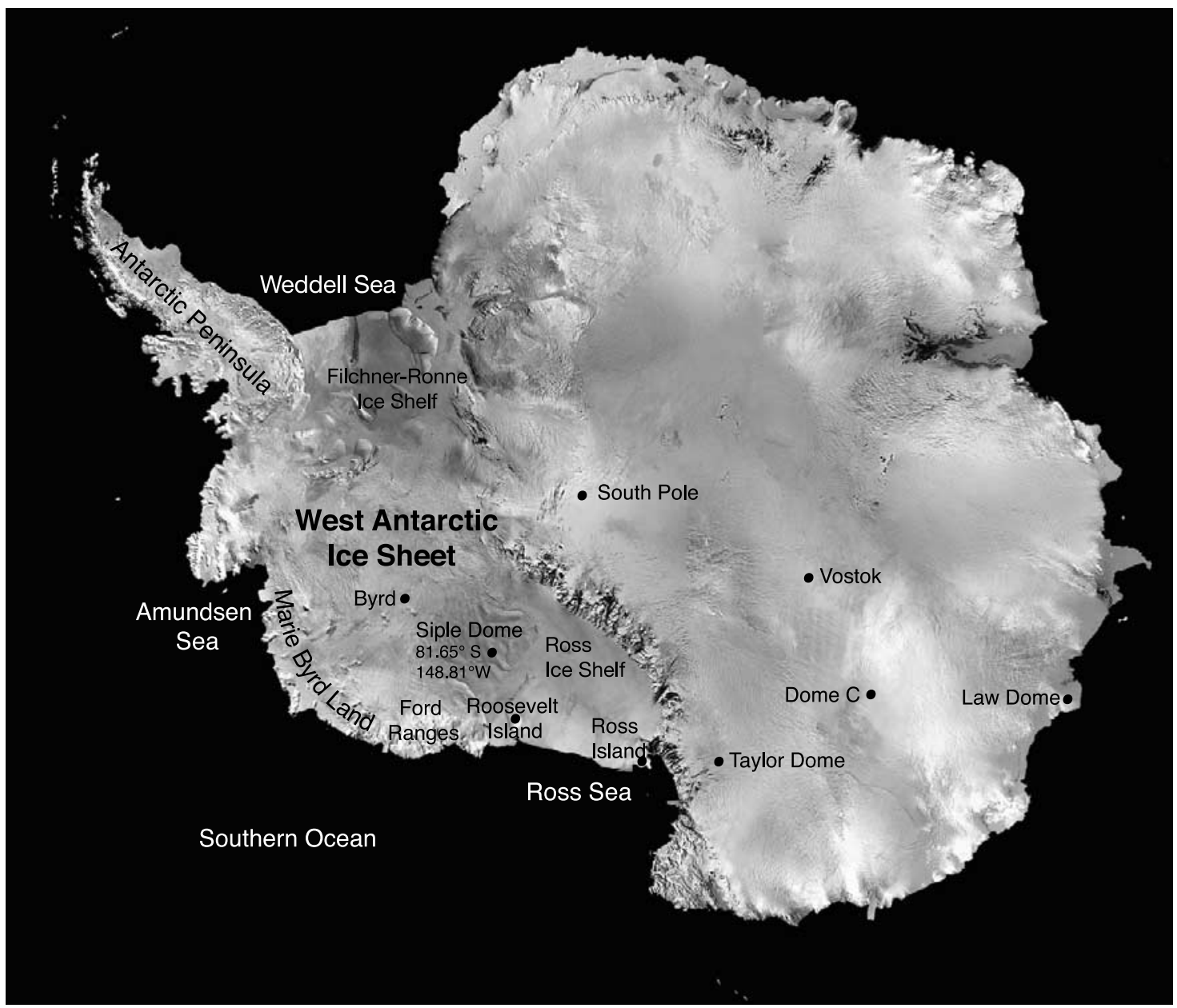

Figure 1. AVHRR image showing the location of the Siple Dome ice core and other Antarctic ice core sites and additional geographic locations discussed in this study.

decreasing through the middle to late Holocene in response to reductions in summer insolation levels and summer temperatures. Melt layer records also offer the possibility of assessing seasonal climate change, since melt features are by their very nature a record of changing summer temperature conditions. This adds a unique seasonal perspective to previously established paleothermometry methods such as stable isotope ratios and borehole thermometry. Melt layer records may also provide new insights into mechanisms of climate change, such as variations in ocean or atmospheric circulation, which may not be clear from mean annual paleotemperature records alone [Alley et al., 1999].

[5] In this study, we extend the use of ice core melt layer records to the Antarctic. Our recent work on melt layer distribution and experimental melt layer formation in West Antarctica showed potential for longer temporal records of Antarctic melt events to provide histories of summer warmth [Das and Alley, 2005]. Using visual observations of melt layers preserved in the firn and ice from the Siple Dome ice core $\left(81.65^{\circ} \mathrm{S}, 148.81^{\circ} \mathrm{W}\right)$, which was drilled to bedrock in 1999, we document changes in melt frequency for the Ross Sea region of West Antarctica (Figure 1). We then use this melt history, in conjunction with other available climate records, to provide a unique perspective of changing climate conditions for West Antarctica through the Holocene.

\section{Development of the Ice Core Melt Layer Record}

[6] During the processing of the Siple Dome ice core at the U.S. National Ice Core Lab, we visually examined the entire sectioned length of the core from surface to bedrock $(1003.83 \mathrm{~m})$. This visual stratigraphic analysis serves two main purposes. The first is to aid in the dating of the ice core by counting the annual layers of ice, preserved as alternating light and dark bands (core dating technique and results are described by Taylor et al. [2004a]). In addition to the annual layer counting, we noted all visible features found in the ice, such as volcanic ash layers and melt layers.

[7] Melt layers were identified as thin (generally a few $\mathrm{mm}$ to more than $1 \mathrm{~cm}$ ), bubble-free to nearly bubble-free zones of clear-looking ice with bubbly ice above and below (Figure 2). Rarely, multiple melt layers were found closely grouped (few $\mathrm{cm}$ ) together. These melt layer patterns in the ice core (both individual and groups) match the melt layers found in snow pits and firn cores across West Antarctica [Kreutz et al., 1999; Das and Alley, 2005], and also match 


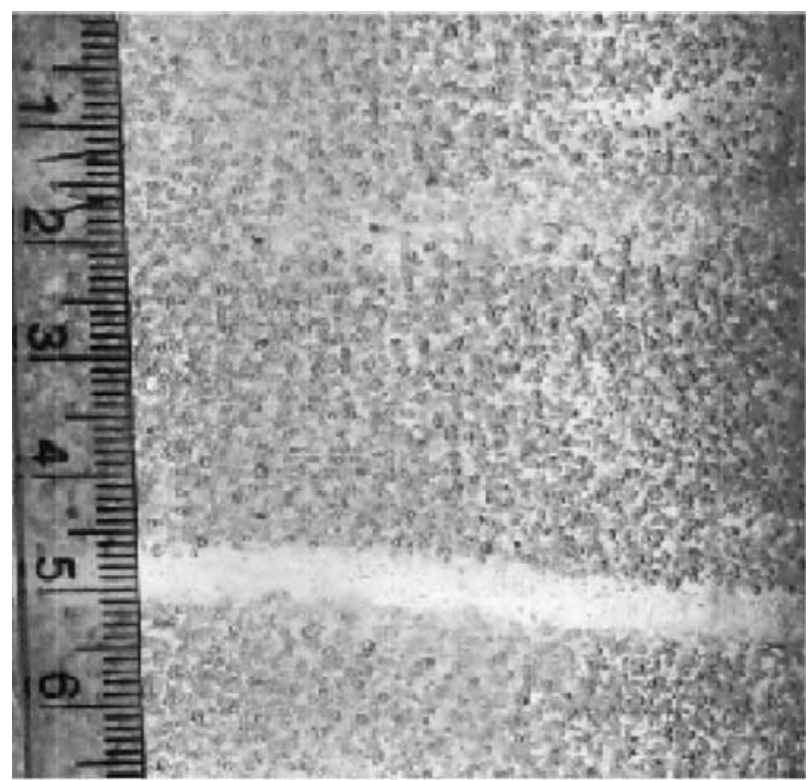

Figure 2. Photograph of a melt layer from the Siple Dome ice core. The melt layer is clearly distinguishable from the surrounding glacial ice by its bubble-free nature and by its linear form and sharp boundaries. Ruler is shown for scale (cm).

the melt layers created during melting experiments at Siple Dome, as described by Das and Alley [2005]. We identified a total of 62 melt events, ranging in depth from $614 \mathrm{~m}$ to $1.8 \mathrm{~m}$. Note that the ice remained bubbly to the bed at Siple Dome, with no transition of bubbles to solid clathrate inclusions, so visible identification of melt layers remained straightforward.

[8] Melt features were dated using the age-depth scale of Taylor et al. [2004a] (see Table 1 for melt layer depths and ages). A melt layer history was created, with each individual year being assigned either $[0=$ no melt $]$ or $[1=$ melt $]$ (Figure 3). Further discussion of the choice of this binary assignment is found in the following section. In this study, we are primarily interested in the millennial record of melt occurrence to describe long-term trends in melt frequency at Siple Dome, and to compare this record to other regional Holocene climate records. To this end, we calculated a 1000-year running mean (each year containing a melt layer is allocated a 1 for $100 \%$ melt frequency for that year, and each year with no melt is allocated a 0 for $0 \%$ melt frequency). Melt events were found to begin close to $12 \mathrm{ka}$; a period of low melting frequency occurs from $11.5 \mathrm{ka}$ to $8.5 \mathrm{ka}$; a period of no melting from $8.5 \mathrm{ka}$ to $7 \mathrm{ka}$; and finally a gradual increase in melt frequency from 7 ka continuing until the present time, with intervals of especially rapid increase beginning at $4 \mathrm{ka}$ and at $2.5 \mathrm{ka}$ (Figure 3). (One additional stratigraphic feature that may be a melt layer was found at a depth corresponding to $15.5 \mathrm{ka}$. This layer is associated with an anomalous interval in the core where nitrogen and argon isotopic data suggest firn thinning, possibly indicating a deposition hiatus between 15.2 and $15.7 \mathrm{ka}$ (discussed further by Brook et al. [2005], Taylor et al. [2004b], and Severinghaus et al. [2003]). Such a hiatus would allow the snow surface to approach a blue- ice-like condition, reducing the albedo, and might explain melting under otherwise quite cold conditions [Liston and Winther, 2005]. Owing to the highly unusual nature of this interval, we do not include this layer in our chronology.)

\section{Integrity of the Melt Layer Record as a Paleoclimate Signal}

[9] Collecting melt layer data from an ice core is relatively easy, if tedious. However, several issues must be considered in converting the raw data into a paleoclimatic record. These include: learning whether ice flow thinning has affected recognition of melt layers; dating individual melt events; determining whether changes over time in melt layer frequency are statistically significant; and estimating whether changes in the ice surface elevation across Siple Dome have affected melt layer frequency independent of climate change. These are discussed individually in more detail below.

\subsection{Expected Degree of Layer Thinning}

[10] As surface layers are advected downward through the ice sheet, they are thinned across the dome. This will affect the thickness of both annual layers and any melt layers we observe, and could potentially impact our ability to detect melt layers in the ice core. In the simplest model, with no basal melting [Engelhardt, 2004] on a steady, infinitely old dome, layers become vanishingly small very close to the bed. This is often modeled using the approximation of Nye [1963], in which the thinning rate does not vary with depth:

$$
1 / 1_{\mathrm{o}}=\mathrm{z} / \mathrm{h}_{\mathrm{o}}
$$

where 1 is the observed layer thickness, the initial layer thickness is $l_{\mathrm{o}}$, the height above the base is $\mathrm{z}$, and the total ice thickness, $h_{o}$ is $979 \mathrm{~m}$ for Siple Dome, calculated by subtracting the $\sim 25 \mathrm{~m}$ of air in the near-surface firn from the total ice thickness of $1003.83 \mathrm{~m}$. Our deepest melt layer is at $589 \mathrm{~m}$ ice depth (614 $\mathrm{m}$ in the borehole), and equation (1) indicates this layer retains $40 \%$ of its initial thickness. The annual layer thickness at this depth is observed to be around $3 \mathrm{~cm}$ [Waddington et al., 2005] whereas a melt layer with an initial $1 \mathrm{~cm}$ thickness at the surface would have thinned to approximately $0.4 \mathrm{~cm}$ at this depth, and would remain a clearly distinct feature within the annual layer. Our experience examining melt layers and thinner crusts in the ice core suggests to us that order-of-magnitude or more thinning would be required to greatly impair melt layer recognition, so we believe that layer thinning has not biased the observed melt layer history.

\subsection{Dating of the Melt Events}

[11] Dating of the melt layers is based on the annually resolved age-depth scale of Taylor et al. [2004a]. This requires the assumption that melt layers are found in ice that accumulated during the year in which the melting occurred. In warmer locations, sufficient meltwater may be generated in summer to allow the water to migrate downward into older firn layers before refreezing, perhaps by as much as a few meters. This opens two possibilities: that an age bias could exist if our meltwater moved 


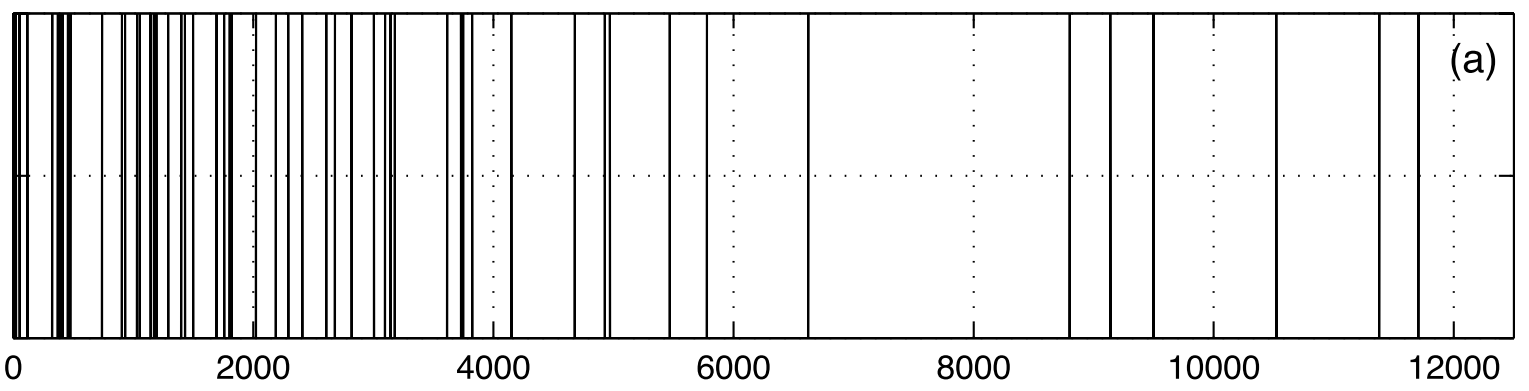

Age of melt layers (years before present)

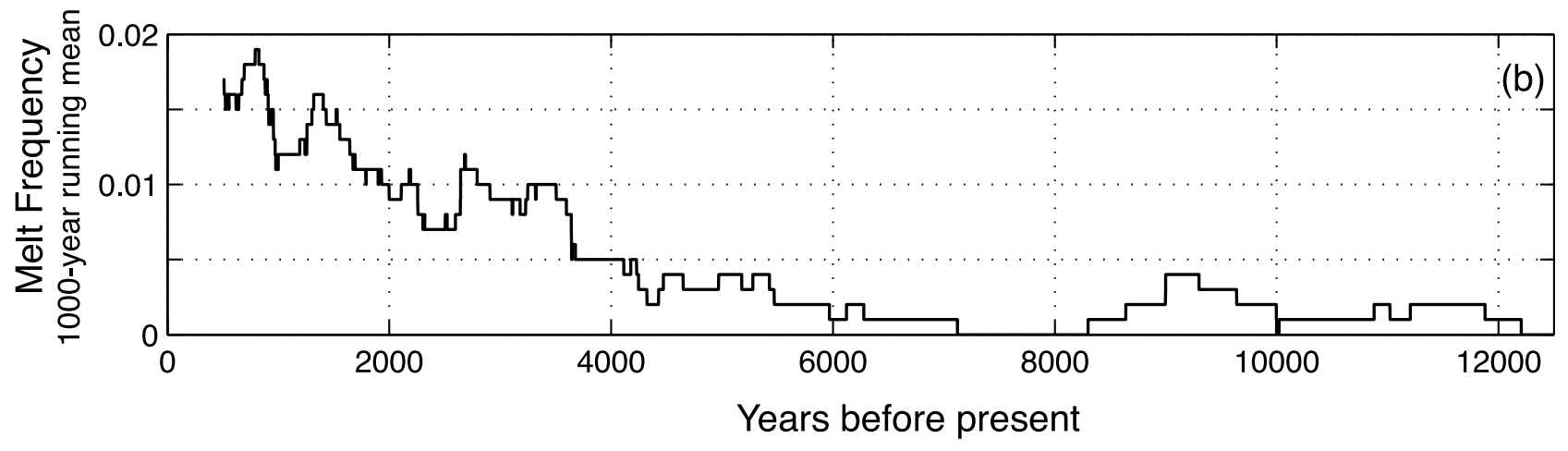

Figure 3. Distribution of melt layers found in the Siple Dome core identified as (a) the age of all of the melt layers included in this study and (b) the 1000 year melt frequency average (1000 year running mean). A melt frequency of 0.01 , for example, indicates a time period when melting occurred on average 10 times every 1000 years.

downward before refreezing, and that a frequency bias could exist if a large melt event produced multiple melt layers by refreezing near the surface and in older firn. However, several arguments allow us to discount these possibilities.

[12] To test these potential biases, experimental work conducted at Siple Dome [Das and Alley, 2005] created artificial melt layers by heating the snow surface at varying intensities for varying lengths of time. In these experiments, melt layers of the type observed in the ice core were created only very near the surface by the refreezing of small amounts of liquid water generated at the surface, with the meltwater spreading along stratigraphic discontinuities (crusts) found at or near the surface [Das and Alley, 2005]. The mean annual accumulation rate at Siple Dome is approximately $0.3 \mathrm{~m}$ of snow/year, whereas the depth of percolation during a natural melt event is projected to be $0.01-0.05 \mathrm{~m}$. Experimental results show that sufficiently intense melting to generate meltwater capable of migrating into firn accumulated during a previous year requires heating sufficiently far outside modern conditions that we do not believe such melting can have occurred during the Holocene [Das et al., 2002; Das and Alley, 2005]. In addition, percolation of water to deeper layers often leaves vertical glands or pipes of ice, but no such features were observed in the Siple Dome deep core, in any of the shallower cores from this region (including eight other cores from Siple Dome as well as cores from Upstream C, Ridge BC and Upstream B [Voigt et al., 1993; Alley and Bentley, 1988]), or in any of the snow pits we dug across the dome [Das and Alley, 2005]. In any event, our melt record shows only three times when two adjacent years contain melt features (Table 1), so the maximum error from this potential (although, as described, unlikely) contamination would be overcounting by three events widely distributed throughout the entire core.

[13] It is likely that a single melt event sometimes forms more than one melt layer within a single summer layer, and the ice core record did include instances where multiple melt layers were found closely grouped (few $\mathrm{cm}$ ) together. Our melting experiments at Siple Dome have demonstrated that melt layers are formed because of preferential flow and subsequent refreezing of meltwater from the surface into near-surface, fine grained crust layers. Multiple crust layers are often found very near the surface (in the top few $\mathrm{cm}$ ) and closely spaced melt layers have in fact been observed in shallow snow pits across Siple Dome [Das and Alley, 2005]. It is also possible that a single summer will have more than one melt event separated by additional snow accumulation. Since we cannot tell whether two melt layers in the firn from a given year represent one or two melting events we chose to identify each year as having melt (melt frequency $=1$ ) or having no melt (melt frequency $=0$ ), rather than giving more weight to years with multiple melt features.

[14] The studies of Das and Alley [2005] showed that stratigraphic vertical discontinuities such as fine-grained crusts and coarse-grain hoar layers play a prominent role in localizing meltwater and thus in the formation of melt layers at Siple Dome. We note, however, that such grain size discontinuities are very common. Our stratigraphic examination of the core shows prominent layering at all depths. 
Table 1. Melt Layer Depths and Ages From Visual Stratigraphic Analysis of the Siple Dome Deep Ice Core

\begin{tabular}{|c|c|}
\hline Depth, m & Age $^{a}$ \\
\hline 1.88 & 11 \\
\hline 5.85 & 23 \\
\hline 11.85 & 53 \\
\hline 23.36 & 118 \\
\hline 50.84 & 325 \\
\hline 56.31 & 371 \\
\hline 57.49 & 382 \\
\hline 59.75 & 401 \\
\hline 60.55 & 409 \\
\hline 61.10 & 414 \\
\hline 65.61 & 455 \\
\hline 65.73 & 456 \\
\hline 67.54 & 472 \\
\hline 68.02 & 476 \\
\hline 95.85 & 740 \\
\hline 112.56 & 905 \\
\hline 115.31 & 932 \\
\hline 125.16 & 1031 \\
\hline 127.32 & 1054 \\
\hline 135.56 & 1144 \\
\hline 137.94 & 1172 \\
\hline 139.84 & 1193 \\
\hline 148.30 & 1291 \\
\hline 157.45 & 1399 \\
\hline 160.16 & 1431 \\
\hline 165.92 & 1499 \\
\hline 182.50 & 1693 \\
\hline 188.00 & 1757 \\
\hline 188.07 & 1758 \\
\hline 191.72 & 1803 \\
\hline 193.05 & 1819 \\
\hline 209.26 & 2022 \\
\hline 221.89 & 2188 \\
\hline 229.58 & 2292 \\
\hline 238.45 & 2408 \\
\hline 252.98 & 2608 \\
\hline 257.80 & 2680 \\
\hline 266.71 & 2818 \\
\hline 278.14 & 3005 \\
\hline 283.89 & 3097 \\
\hline 286.67 & 3141 \\
\hline 286.77 & 3143 \\
\hline 286.84 & 3144 \\
\hline 288.98 & 3179 \\
\hline 314.58 & 3615 \\
\hline 321.21 & 3730 \\
\hline 322.11 & 3748 \\
\hline 326.14 & 3823 \\
\hline 344.68 & 4150 \\
\hline 371.39 & 4678 \\
\hline 383.39 & 4928 \\
\hline 385.49 & 4971 \\
\hline 408.20 & 5469 \\
\hline 421.71 & 5778 \\
\hline 454.33 & 6622 \\
\hline 528.15 & 8800 \\
\hline 538.81 & 9140 \\
\hline 549.98 & 9498 \\
\hline 550.05 & 9500 \\
\hline 580.71 & 10522 \\
\hline 605.22 & 11379 \\
\hline 614.22 & 11705 \\
\hline
\end{tabular}

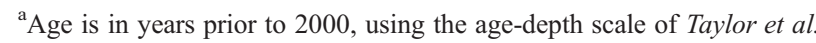
[2004a].

Thus we do not believe that changes in melt layer frequency could reflect changes in occurrence of such discontinuities, and instead we argue that occurrence of meltwater is the controlling variable.

\subsection{Melting as a Statistically Significant Event}

[15] We used a $\chi^{2}$ test to investigate whether the distribution of melt events through the Holocene observed in the Siple Dome deep ice core is statistically different from the Poisson distribution expected if melting has been a random process (method after Alley and Anandakrishnan [1995]). To do this, we assessed the differences between histograms of the actual waiting times between observed events and Poisson-distributed events with the same mean waiting time as observed. We ran 1000 Monte Carlo Poisson simulations to generate a synthetic melt time series in which the waiting time between Poisson events is exponentially distributed. The Poisson parameter (L) was calculated from the mean waiting time between events (M) of 193.5 years, based on our actual ice core melt layer series with 62 events in 12,000 years:

$$
\mathrm{L}=1 / \mathrm{M}=1 / 193.5 \text { years. }
$$

We separated results from both the observed ice core waiting periods and the Poisson-simulated waiting periods into 16 equivalent bins (bins based on waiting times in years, centered on $(50,150, \ldots 1450,1550)$. The 1000 simulated values are also scaled down to 62 values $\left(E_{\mathrm{s}}\right)$ in order to compare them to the 62 observed values. The $\chi^{2}$ statistic with $\mathrm{O}=$ observed (ice core) and $\mathrm{E}_{\mathrm{s}}=$ expected (Poisson, scaled) $\chi^{2}$ is calculated as:

$$
\chi^{2}=\sum\left(\mathrm{O}-\mathrm{E}_{\mathrm{s}}\right)^{2} / \mathrm{E}_{\mathrm{s}}
$$

The result is $\chi^{2}=50.5$ summed over 16 bins. For this case of 16 bins, with $\nu=15$ degrees of freedom, the critical value of $\chi^{2}=30$ is required for a $99 \%$ confidence level [Abramowitz and Stegun, 1970]. Our value of $\chi^{2}=50.5$ is well above the $99 \%$ confidence level for this scenario, supporting the case for a nonrandom distribution process. Thus we can be confident that variations in the melt layer record through the Holocene are not reflecting random variability.

\subsection{Core Site Elevation and Flow History}

[16] Knowledge of changes in ice sheet surface elevation during the deglaciation across West Antarctica, and in particular at Siple Dome, is critical to interpreting the climate history recorded by the Siple Dome ice core, because elevation affects local temperature (a wet adiabatic lapse rate would correspond to slightly less than $1^{\circ} \mathrm{C}$ change for each $100 \mathrm{~m}$ elevation change). For the present study, we focus on ice sheet models that derive ice thickness changes by matching measured ice sheet characteristics (temperature, ice fabric, internal stratigraphy) to modeled perturbations in elevation and ice flow while accounting for climate history (accumulation rate, temperature, gas concentrations) using independently derived data.

[17] Constraints on the elevation history have been very sparse until recently, and still remain less abundant than desired, so it is unsurprising that previously published elevation histories vary widely for the WAIS. Thinning estimates at Siple Dome from the LGM to the present range from $700 \mathrm{~m}$ or more [e.g., Denton and Hughes, 2002], to 200-400 m [Waddington et al., 2005], to less than $100 \mathrm{~m}$ 

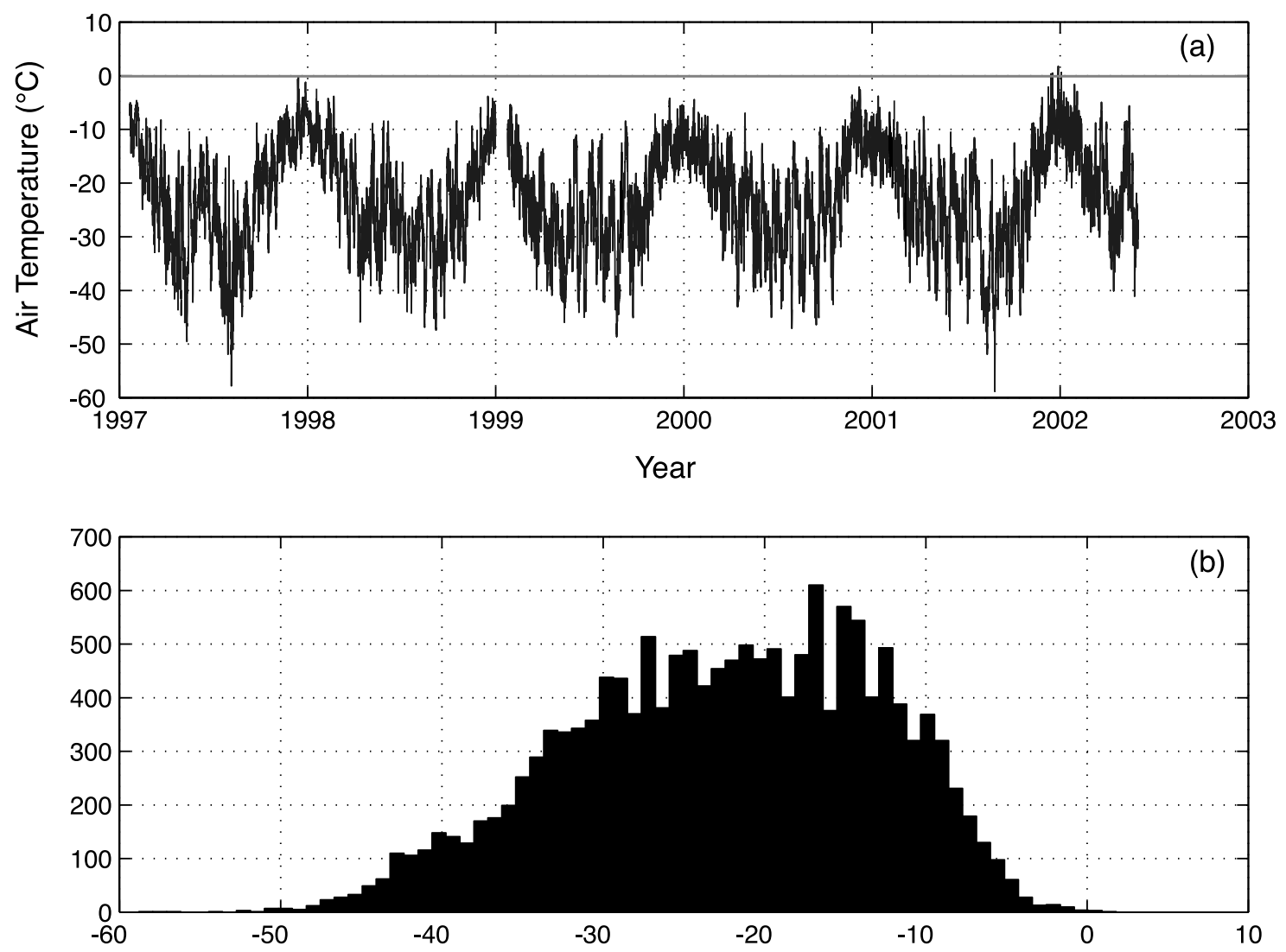

Air Temperature ( C)

Figure 4. (a) Five year time series of 3-hourly Siple Dome air temperature from 1997 to 2002 from the University of Wisconsin Automatic Weather Station data and (b) corresponding histogram of temperature distribution over the same time period. Note the rapid transition from winter to summer conditions and the short length of the summer season. Temperatures above $-5^{\circ} \mathrm{C}$ are rare and occur for very brief intervals. There is a brief interval of air temperatures above $0^{\circ} \mathrm{C}$ seen during the $2001-2002$ summer. We do not believe this was of sufficient intensity or duration to cause surface melting or to create melt layers. Although we have no field observations from this time (or after), an examination of the passive microwave record (SSM/I brightness temperature) through this period also shows no melt event.

[Parizek and Alley, 2004]. The most recent and most comprehensive study is by Price et al. [2007], using a two-dimensional, full-stress, thermomechanical flow band model, and provides what we believe is the best constrained scenario available for Siple Dome. Their favored result yields $350 \mathrm{~m}$ of thinning at Siple Dome since the LGM, primarily occurring between 15,000 and 14,000 years ago, well before the onset of summer melting. The studies of Waddington et al. [2005] and Price et al. [2007] concur that little change has occurred over the Holocene, and especially over the last few millennia when the changes in melt layer occurrence are largest. (We also note that the total-gascontent technique, while sensitive to large elevation changes, typically will not be accurate for such small changes [Raynaud et al., 1997].)

\section{Melt Frequency as a Record of Summer Temperature}

[18] Surface melting is a rare phenomenon across most of West Antarctica, including the Siple Dome region [Liu et al., 2006; Das and Alley, 2005; Zwally and Fiegles, 1994]. Melt layers record "extreme events" in a statistical sense, occurring in response to air temperatures exceeding a certain threshold (Figure 4). Changes in melt frequency through time therefore reflect changes in the frequency with which air temperatures exceed this threshold through time. An increase in melt may be achieved by increase in mean summer temperature, increase in summer temperature variability, or some combination thereof [cf. Alley and Anandakrishnan, 1995].

[19] We argue, however, that available evidence suggests that the changes in melt frequency can be interpreted as primarily reflecting changes in mean summer temperature. At many times, regions of ice sheet margins, mountain glaciers, seasonal snow cover, permafrost, and seasonally frozen ground experience melting during hot days or following warm-front passage, alternating with subfreezing conditions at night or following cold-front passage. In those times and places, an increase in variability would increase melting, and yet, widespread experience shows that changes in melting typically result from changes in mean tempera- 


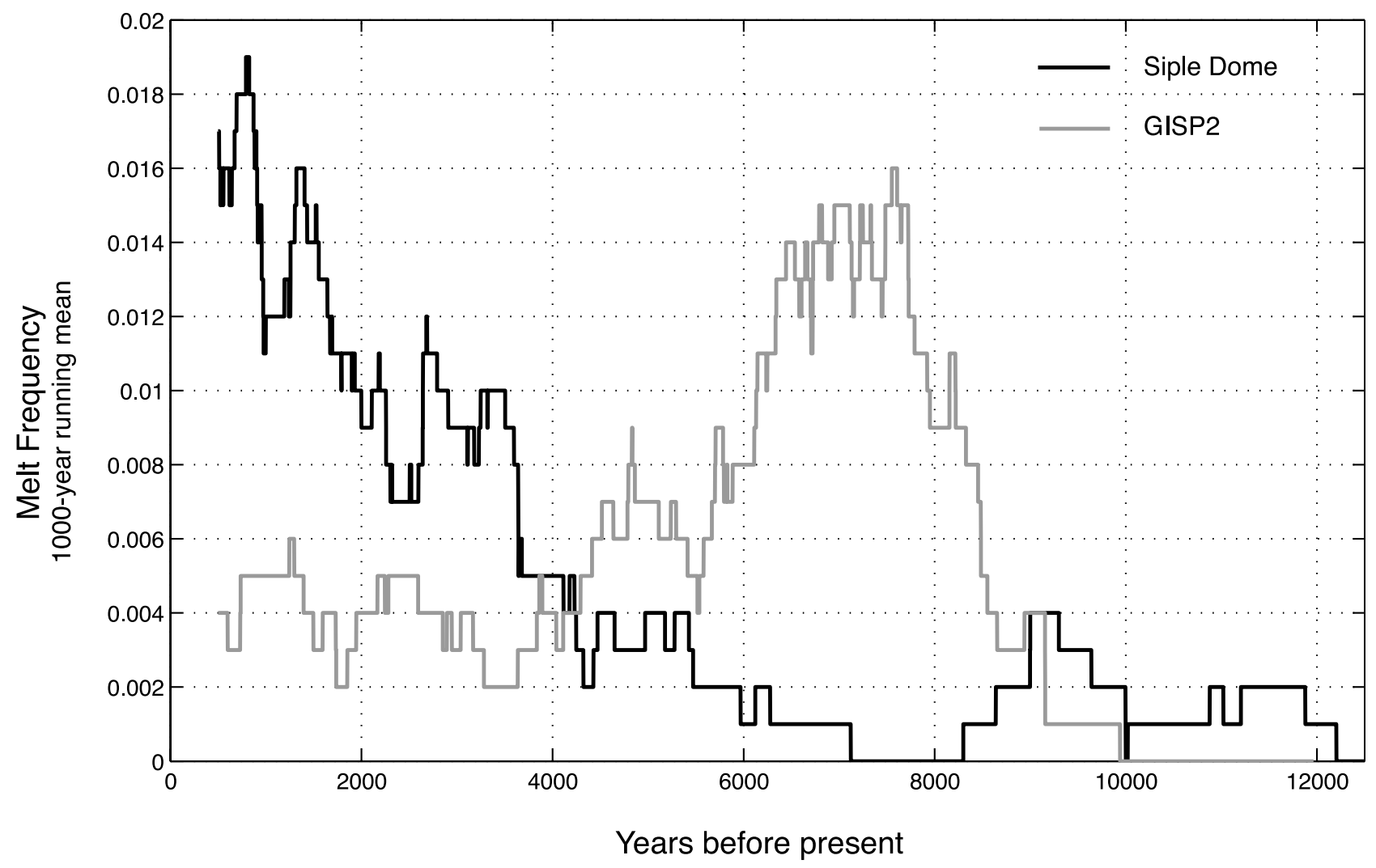

Figure 5. Frequency range of melt events at Siple Dome (solid, this study) and those observed at GISP2 in central Greenland (shaded [Alley and Anandakrishnan, 1995]) through the Holocene. The similar scale in frequency change allow us to use the Greenland record to help calibrate the temperature change at Siple Dome.

ture [e.g., Oerlemans, 2001; Lemke et al., 2007]. Similarly, snowmelt and ice melt calculations based on an established linear relationship between melt rate and positive degree days [Braithwaite, 1995; Reeh, 1991] are found to closely match more sophisticated models of surface melt and runoff, supporting this relationship between mean summer temperature and surface melt [Reeh et al., 2005; Ohmura, 2001]. We consider the possibility of an overprint from changing variability to be an interesting research question, but in this study we follow the generally validated practice in the field and interpret changing melt as a signature of changing mean summertime temperature.

[20] We calibrate the Siple Dome melt layer record in two independent ways to allow estimation of the actual temperature increase required to explain the increase in melt frequency over the middle- to late-Holocene. The first calibration (a comparison to Greenland records) and the second calibration (a site-specific calibration for Siple Dome), agree closely.

[21] The frequency range of melt events at Siple Dome is similar to the frequency range observed in central Greenland (Figure 5). Greenland melt frequencies range from 0.004 per year in the late Holocene to 0.016 per year in the middle Holocene in the GISP2 core, and 0.03 in the late Holocene at nearby Greenland Site A (GS-A), which is $2^{\circ} \mathrm{C}$ warmer than GISP2. In the work by Alley and Anandakrishnan [1995], two calibrations (the simple comparison between GISP2 and GS-A, and a second based on a statistical model extrapolating from a few years of automatic weather station data at the GISP2 site) agreed closely. The fourfold change in melt layer frequency from middle to late Holocene at GISP2 represented a temperature change of about $1.3^{\circ} \mathrm{C}$, and the 7.5-fold difference in late-Holocene melt layer frequency between GISP2 and GS-A represented a temperature difference of $2^{\circ} \mathrm{C}$ (the probabilistic nature of the calibrations causes the nonlinearity). Because the typical middle-Holocene frequency of melt layer occurrence at Siple Dome is roughly 7.5-fold lower than the late-Holocene value, and the minimum middle-Holocene value represents a slightly larger change, analogy suggests a Holocene temperature change at Siple Dome of slightly more than $2^{\circ} \mathrm{C}$.

[22] A Siple Dome-specific calibration would be preferable. Our experiments and observations indicate that a melt layer can form during a single warm day. Examination of automatic weather station data (1997-2002, from the Antarctic Meteorological Research Center (AMRC) (http:// amrc.ssec.wisc.edu/)) suggests that the warm summer, during which melting is plausible, lasts for about 2 months or 61 days. We observed 15 years with melt layers in the last 1000 years (equivalent to 61,000 summer days) at Siple Dome. Assuming that each melt layer represents a single anomalously warm summer day, this represents a melting frequency of $15 / 61000=0.00025$ per day. Assuming further that the relevant temperatures are normally distributed, melting occurs when daily temperature exceeds its mean summertime value by at least 3.5 standard deviations. 


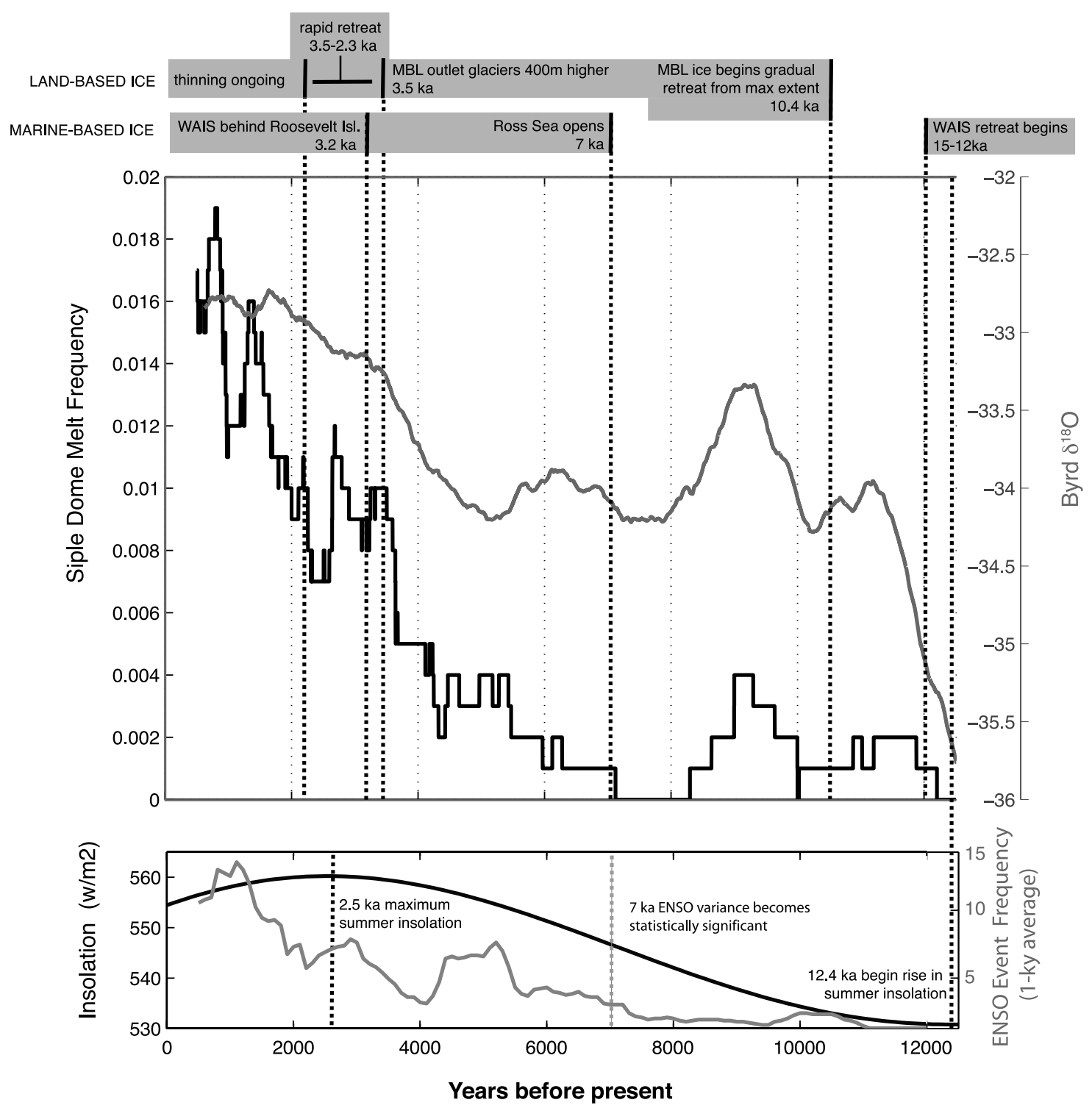

Figure 6. West Antarctic climate change and possible forcings. (top) Millennial-scale changes in Holocene climate across West Antarctica as reflected in the Siple Dome melt frequency (solid, this study) and Byrd $\delta^{18} \mathrm{O}$ (shaded [after Johnsen et al., 1972]). (bottom) Forcing factors that may have contributed to the observed climate changes, including summer $\left(21\right.$ December) insolation at $81^{\circ} \mathrm{S}$ (solid [Berger and Loutre, 1991]) and 1-ky-average ENSO event variability (shaded [after Moy et al., 2002]). The timing of changes in WAIS configuration is shown by shaded bars at the top, for the lateral ice extent in the Ross Sea (labeled "marine-based ice" [Conway et al., 1999; Anderson et al., 2002]) and for the vertical extent of the ice as determined against nunataks near the Marie Byrd Land coast (labeled "land-based ice" [Ackert et al., 1999; Stone et al., 2003]).

[23] The longest interval without a melt layer in the Holocene is 2178 years. If we assign a melt rate of $1 /$ 2179 per year or $1 / 132919$ per day to that middle-Holocene interval, and assume that the change in melt frequency resulted from a change in mean summertime temperature rather than from a change in variability (see above), then the temperature during that middle-Holocene cold interval was about 0.8 standard deviations lower than during the most recent millennium.

[24] We next estimate the temperature standard deviation, to allow calculation of the Holocene warming at Siple Dome in degrees rather than in standard deviations. We extracted the average temperature of each summer day, $\mathrm{T}_{\mathrm{SU} \_\mathrm{i}}$, from the 3-h automatic weather station data. The mean of these data is $\mathrm{T}_{\mathrm{SU}}=-11.5^{\circ} \mathrm{C}$, or $11.8^{\circ} \mathrm{C}$ below the threshold for melt layer formation from our field experiments [Das, 2003]. Still assuming normally distributed data, the calculation above showing that over the last millennium melting has occurred on days at least 3.5 standard deviations above the mean then implies a standard deviation of $3.4^{\circ} \mathrm{C}$. Alternately, we simply calculate the standard deviation of the $\mathrm{T}_{\mathrm{SU}_{-} \mathrm{i}}$, obtaining $3.1^{\circ} \mathrm{C}$. These imply that the Siple Dome summertime warming of 0.8 standard deviations is $2.5^{\circ} \mathrm{C}$ to $2.7^{\circ} \mathrm{C}$, reassuringly consistent with the 
central Greenland calibration. One cannot rule out arbitrarily cold conditions during the middle-Holocene time of zero melting, so the warming might have been larger than this.

\section{Holocene Melt Record as Evidence for Increasing Marine Influence on the Climate of West Antarctica}

[25] Midsummer insolation at the latitude of Siple Dome increased through the early to middle Holocene, with maximum values reached by $2.5 \mathrm{ka}$ [Berger and Loutre, 1991]. The most rapid rise in melt frequency, though, occurs more recently than the rapid rise in insolation, and melt frequency continued to rise after insolation values began to decrease again after $2.5 \mathrm{ka}$ (Figure 6). We therefore suggest that additional factors must be responsible for the variations in Holocene climate conditions at Siple Dome as recorded by melt frequency. Available data make two hypotheses especially likely: changes in the configuration of the West Antarctic Ice Sheet; and/or changes in the ocean/atmosphere behavior in the Ross Sea and the Southern Ocean.

[26] The WAIS is relatively maritime in nature compared to the higher, colder East Antarctic ice sheet, and Siple Dome's climate is strongly influenced by coastal conditions in the Ross Sea and South Pacific region. This is a region of intense cyclogenesis, and the low elevation, low slope and smoothness of the WAIS allow low-pressure systems to propagate far inland, advecting warm air and moisture, before dissipating [Bromwich, 1988; Kreutz et al., 1997]. Summer heating is likely to be forced in part by the lateral advection of warm, moist maritime air across the Ross Sea embayment ice shelf/ice sheet system. An increase in this source of heating could be caused by a combination of multiple factors: an increase in the sea surface temperature; an increase in the rate of deep water formation in the Ross Sea releasing more heat to the local atmosphere; an increase in the number of low-pressure systems or storminess; and/or a decrease in the distance to open water as manifested by changes in the WAIS grounding line, ice sheet elevation and sea ice extent. Many of these mechanisms, which are primarily marine in nature, could in turn be driven by changes in ENSO variability, changes in the Antarctic Circumpolar Wave, changes in the Antarctic Circumpolar Current, and/or changes in global thermohaline circulation (as has been shown for many of them on shorter timescales during recent times [e.g., Zwally et al., 1983; Carleton, 1988; Carleton et al., 1998; Kwok and Comiso, 2002; Ledley and Huang, 1997; Hanna, 2001; Bromwich et al., 2000; Smith and Stearns, 1993]).

[27] Weather patterns in West Antarctica are known to follow the position of the persistent Ross Sea polar low over the southern Pacific Ocean [Bindschadler, 2006]. Variations in both wind direction and precipitation across WAIS today are driven by the position of this low, which in turn is strongly controlled by the alternating La Niña and El Niño phases of the southern oscillation, although the causal mechanisms are still being investigated [Bromwich et al., 2000]. It is therefore likely that variations in summer temperature across West Antarctica would also be strongly impacted by the location of this low, and therefore by ENSO variability. Moy et al. [2002] have in fact shown that the Holocene is also characterized by millennial-scale oscilla- tion in 100-year ENSO event frequency. ENSO events are found to increase toward the present, with statistically significant millennial-scale variability beginning around $7 \mathrm{ka}$ and culminating at $1.2 \mathrm{ka}$, characterized by gradual pulsing that increases in frequency toward the present. A comparison between this Holocene ENSO record and the Siple Dome melt frequency record demonstrate a remarkable correlation in the millennial band (Figure 6).

[28] In addition to the local ice sheet elevation history at Siple Dome discussed in section 3.4, above, the lateral and vertical extent of the WAIS likely also impacted the climate at Siple Dome, especially the ability of cyclonic systems to penetrate inland. Uncertainties remain, but recent marine and terrestrial geologic studies increasingly constrain the timing of the drawdown and retreat [Shipp et al., 1999; Anderson et al., 2002; Anderson and Shipp, 2001; Ackert et al., 1999; Conway et al., 1999; Stone et al., 2003]. The emerging view is that the initial retreat of WAIS began between 15 and $12 \mathrm{ka}$ (possibly earlier on the outer continental shelf) and that this retreat is continuing today or stabilized only recently [Anderson et al., 2002; Stone et al., 2003]. The grounding line retreated past Ross Island between $7 \mathrm{ka}$ and present, and past Roosevelt Island around $3.2 \mathrm{ka}$ [Conway et al., 1999]. This is important evidence that most of the grounding line retreat across the Ross Sea Embayment took place during the middle- to late-Holocene, at the same time there was little to no change in surface elevation across Siple Dome (as described in section 3.4). On land, geologic evidence shows that mountain ranges in Marie Byrd Land (north of the Siple Coast) were overrun by thicker ice during LGM, and deglaciation was still in progress at $3.5 \mathrm{ka}$ with outlet glaciers $400 \mathrm{~m}$ above their present level. In addition, the maximum ice elevation in Marie Byrd Land appears to have occurred after global deglaciation had begun and after initiation of grounding line retreat of the Marie Byrd Land sector of WAIS from its extended position on the continental shelf [Ackert et al., 1999; Stone et al., 2003]. Taken together, these findings motivate our hypothesis that late-Holocene warming observed at Siple Dome reflects increasing marine influence and not just orbital forcing (see the map in Figure 1 for the locations discussed here).

[29] There are presently few high-resolution West Antarctic Holocene climate records available for comparison, or with which to test possible mechanisms of WAIS climate change. The Siple Dome Holocene melt frequency closely resembles features of the Byrd stable isotope record, in particular exhibiting an early Holocene peak, followed by a decrease and then a larger middle- to late-Holocene rise in melt and $\delta^{18} \mathrm{O}$ (Figure 6). The rapid increase in Byrd $\delta^{18} \mathrm{O}$ beginning at $4.5 \mathrm{ka}$ is consistent with a corresponding $\sim 2{ }^{\circ} \mathrm{C}$ increase in temperature [Johnsen et al., 1972], similar to the magnitude of middle- to late-Holocene temperature increase derived from our melt layer calibration. Such a middle- to late-Holocene temperature rise is absent in all East Antarctic ice core records (e.g., Law Dome, Dome C, Vostok and Taylor Dome), which show instead an early Holocene climatic optimum $\left(1-2^{\circ} \mathrm{C}\right.$ warmer than today, from 11 to $8 \mathrm{ka}$ ) followed by a few thousand years of cooling and a stable temperature in the late Holocene [e.g., Masson et al., 2000] Because of this discrepancy between Byrd and the other Antarctic ice core records, the middle- to late- 
Holocene rise in $\delta^{18} \mathrm{O}$ at Byrd has often been attributed to a change in local ice thickness or a change in moisture supply affecting the isotopic signal [e.g., Steig et al., 2000; Jouzel et al., 2001; Morgan and van Ommen, 1997; Ciais et al., 1994]. However, coupled with the recent results described above that Siple Dome (and possibly interior WAIS) elevation change may have been smaller than early reconstructions suggested, we propose the similarities between the Byrd isotopic record and Siple Dome melt record shown here indicate that the WAIS in general may have experienced different Holocene climate conditions from the rest of the Antarctic Ice Sheet, and that these records are robust.

\section{Conclusions}

[30] A unique record of melt layers preserved in the firn and ice from the Siple Dome ice core shows significant millennial-scale changes in melt frequency in the Holocene. Melting events began around $11.7 \mathrm{ka}$, during the time of the widespread Antarctic climatic optimum [e.g., Masson et al., 2000], followed by an extended period of no melting from 8.8 to $6.6 \mathrm{ka}$. Melt layer frequency then generally increased from $6.6 \mathrm{ka}$ to the present, with the 1000 -year-average melt layer frequency reaching a maximum of $2 \%$ at $0.8 \mathrm{ka}$. We argue that melt layer frequency most likely reflects changes in summertime temperatures, and we propose a calibration suggesting that this rise in melt frequency from $0 \%$ to $2 \%$ represents a summer temperature increase of $\geq 2{ }^{\circ} \mathrm{C}$. This temperature change cannot be explained by local change in ice elevation nor entirely by changing summer insolation, and is in contrast to East Antarctic climate records, which show an early Holocene climatic optimum followed by stable or decreasing temperature.

[31] We have used this melt history, in conjunction with other available glaciological and climate records, to provide perspective on changing climate conditions for West Antarctica through the Holocene. We suggest that in addition to the smoothly increasing summer insolation through the middle-Holocene (reaching a maximum at $2.5 \mathrm{ka}$ ), two primary factors are responsible for the millennial-scale variations in middle- to late-Holocene climate conditions at Siple Dome expressed by our melt frequency records. First, we hypothesize that the retreat of the West Antarctic Ice Sheet from its ice age maximum, in particular the opening of the Ross Sea between $7 \mathrm{ka}$ and $3.2 \mathrm{ka}$, and the drawdown of the land-based ice in coastal Marie Byrd land between $3.5 \mathrm{ka}$ and the present, allowed a moderated maritime climate to more easily reach West Antarctica, causing the rapid increase in melt frequency, and interpreted warming, especially after $4 \mathrm{ka}$. Secondly, strong Holocene millennial variability in melt layer frequency is observed, and is not easily explained by the smoother variations in orbital parameters nor ice sheet configuration. This suggests that changes in the ocean/atmosphere behavior in the Ross Sea and the Southern Ocean, in particular periods of increased cyclogenesis, perhaps related to variations in ENSO, may be causing the higher-frequency melt variability seen in our records. Comparison of the melt layer frequency record with the ENSO record of Moy et al. [2002] shows similar millennial-scale variability in the middle to late Holocene, lending support to this hypothesis. The addition of future chemical and thermal records from
Siple Dome will allow us to test these specific hypotheses more robustly. Given the recently demonstrated extreme longitudinal differences found between East and West Southern Hemisphere records over just the last few centuries [Fisher, 2002], there is clearly a need for many more high-resolution Holocene-length sedimentary and ice core records from West Antarctica and the Southern Ocean to investigate these higher-frequency changes and mechanisms in more detail.

[32] Acknowledgments. This research was supported by NSF grant OPP-9814485 and NASA grant NAG5-7776 to Penn State University and by a NASA Earth System Science Graduate Fellowship and a WHOI Postdoctoral Scholar Fellowship to S. Das. Additional support to R. Alley at PSU is from NSF grants 0440899, 0440447, and 0424589 and the Comer Science and Education Foundation. We thank Matthew Spencer, Todd Dupont, and the staff at NICL with assistance in melt layer counting and the facilities used in the visual stratigraphy of the ice cores. We thank Sridhar Anandakrishnan for assistance with the statistical tests. We thank Delia Oppo for helpful discussions regarding Holocene ENSO records. We also thank David Fisher, Roy Koerner, and two anonymous reviewers for their comments that improved the content and clarity of the manuscript.

\section{References}

Abramowitz, M., and I. A. Stegun (1970), Handbook of Mathematical Functions, Dover, Mineola, N. Y.

Ackert, R. P., D. J. Barclay, H. W. Borns, P. E. Calkin, M. D. Kurz, J. L. Fastook, and E. J. Steig (1999), Measurements of past ice sheet elevations in interior West Antarctica, Science, 286(5438), 275-280.

Alley, R. B., and S. Anandakrishnan (1995), Variations in melt-layer frequency in the GISP2 ice core: Implications for Holocene summer temperatures in central Greenland, Ann. Glaciol., 21, 64-70.

Alley, R. B., and C. R. Bentley (1988), Ice-core analysis on the Siple Coast of West Antarctica, Ann. Glaciol., 11, 1-7.

Alley, R. B., A. M. Agusdsdottir, and P. J. Fawcett (1999), Ice-core evidence of Late-Holocene reduction in North Atlantic ocean heat transport, in Mechanisms of Global Climate Change at Millenial Time Scales, Geophys. Monogr. Ser., vol. 112, edited by P. U. Clark, R. S. Webb, and L. D. Keigwin, pp. 301-312, AGU, Washington, D. C.

Anderson, J. B., and S. S. Shipp (2001), Evolution of the West Antarctic Ice Sheet, in The West Antarctic Ice Sheet: Behavior and Environment, Antarct. Res. Ser., vol. 77, edited by R. B. Alley and R. Bindschadler, pp. 45-57, AGU, Washington, D. C.

Anderson, J. B., S. S. Shipp, A. L. Lowe, and J. S. Wellner (2002), The Antarctic Ice Sheet during the Last Glacial Maximum and its subsequent retreat history: A review, Quat. Sci. Rev., 21(1-3), 49-70.

Berger, A., and M. F. Loutre (1991), Insolation values for the climate of the last 10,000,000 years, Quat. Sci. Rev., 10(4), 297-317.

Bindschadler, R. (2006), The environment and evolution of the West Antarctic ice sheet: Setting the stage, Philos. Trans. R. Soc. London, Ser. A, 364(1844), 1583-1605.

Braithwaite, R. J. (1995), Positive degree-day factors for ablation on the Greenland Ice Sheet studied by energy-balance modeling, J. Glaciol., 41(137), $153-160$

Bromwich, D. H. (1988), Snowfall in high southern latitudes, Rev. Geophys., 26(1), 149-168.

Bromwich, D. H., A. N. Rogers, P. Kallberg, R. I. Cullather, J. W. C. White, and K. J. Kreutz (2000), ECMWF analyses and reanalyses depiction of ENSO signal in Antarctic precipitation, J. Clim., 13(8), 1406-1420.

Brook, E. J., J. W. C. White, A. S. M. Schilla, M. L. Bender, B. Barnett, J. P. Severinghaus, K. C. Taylor, R. B. Alley, and E. J. Steig (2005), Timing of millennial-scale climate change at Siple Dome, West Antarctica, during the last glacial period, Quat. Sci. Rev., 24, 1333-1343.

Carleton, A. M. (1988), Sea ice-atmosphere signal of the Southern Oscillation in the Weddell Sea, Antarctica, J. Clim., 1(4), 379-388.

Carleton, A. M., G. John, and R. Welsch (1998), Interannual variations and regionality of Antarctic sea-ice- temperature associations, Ann. Glaciol., 27, 403-408.

Ciais, P., J. Jouzel, and J. R. Petit (1994), Holocene temperature variations inferred from six Antarctic ice cores, Ann. Glaciol., 20, 427-436.

Conway, H., B. L. Hall, G. H. Denton, A. M. Gades, and E. D. Waddington (1999), Past and future grounding-line retreat of the West Antarctic Ice Sheet, Science, 286(5438), 280-283.

Das, S. B. (2003), West Antarctic Ice Sheet surface melting and Holocene climate variability, Ph.D. thesis, 151 pp., Pa. State Univ., University Park. 
Das, S. B., and R. B. Alley (2005), Characterization and formation of melt layers in polar snow: Observations and experiments from West Antarctica, J. Glaciol., 51(173), 307-312.

Das, S. B., R. B. Alley, D. B. Reusch, and C. A. Shuman (2002), Temperature variability at Siple Dome, West Antarctica, derived from SSM/I and SMMR brightness temperatures, ECMWF re-analyses and AWS records, Ann. Glaciol., 34, 106-112.

Denton, G. H., and T. J. Hughes (2002), Reconstructing the Antarctic Ice Sheet at the Last Glacial Maximum, Quat. Sci. Rev., 21(1-3), 193-202.

Engelhardt, H. (2004), Ice temperature and high geothermal flux at Siple Dome, West Antarctica, from borehole measurements, J. Glaciol., 50(169), 251-256.

Fahnestock, M. A., W. Abdalati, and C. A. Shuman (2002), Long melt seasons on ice shelves of the Antarctic Peninsula: An analysis using satellite-based microwave emission measurements, Ann. Glaciol., 34, $127-133$.

Fisher, D. A. (2002), High-resolution multiproxy climatic records from ice cores, tree-rings, corals and documentary sources using eigenvector techniques and maps: Assessment of recovered signal and errors, Holocene, $12(4), 401-419$.

Fisher, D. A., R. M. Koerner, and N. Reeh (1995), Holocene climatic records from Agassiz Ice Cap, Ellesmere Island, NWT, Canada, Holocene, 5, 19-24.

Hanna, E. (2001), Anomalous peak in Antarctic sea-ice area, winter 1998, coincident with ENSO, Geophys. Res. Lett., 28(8), 1595-1598.

Herron, M. M., S. L. Herron, and C. C. Langway (1981), Climatic signal of ice melt features in southern Greenland, Nature, 293, 389-391.

Johnsen, S. J., W. Dansgaard, H. B. Clausen, and C. C. Langway (1972), Oxygen isotope profiles through the Antarctic and Greenland ice sheets, Nature, 235(5339), 429-434.

Jouzel, J., et al. (2001), A new 27 ky high resolution East Antarctic climate record, Geophys. Res. Lett., 28(16), 3199-3202.

Kameda, T., H. Narita, H. Shoji, F. Nishio, Y. Fujii, and O. Watanbe (1995), Melt features in ice cores from Site J, southern Greenland: Some implications for summer climate since AD 1550, Ann. Glaciol., 21, 51-58.

Koerner, R. M. (1977), Devon Island ice cap: Core stratigraphy and paleoclimate, Science, 196, 15-18.

Kreutz, K. J., P. A. Mayewski, L. D. Meeker, M. S. Twickler, S. I. Whitlow, and I. I. Pittalwala (1997), Bipolar changes in atmospheric circulation during the Little Ice Age, Science, 277(5330), 1294-1296.

Kreutz, K. J., P. A. Mayewski, M. S. Twickler, S. I. Whitlow, J. W. C. White, C. A. Shuman, C. F. Raymond, H. Conway, and J. R. McConnell (1999), Seasonal variations of glaciochemical, isotopic and stratigraphic properties in Siple Dome (Antarctica) surface snow, Ann. Glaciol., 29, $38-44$.

Kwok, R., and J. C. Comiso (2002), Southern Ocean climate and sea ice anomalies associated with the Southern Oscillation, J. Clim., 15(5), 487501.

Langway, C. C., and H. Shojii (1990), Past temperature record from the analysis of melt features in the Dye 3, Greenland, ice core, Ann. Glaciol., $14,343-344$.

Ledley, T. S., and Z. Huang (1997), A possible ENSO signal in the Ross Sea, Geophys. Res. Lett., 24(24), 3253-3256.

Lemke, P., et al. (2007), Observations: Changes in snow, ice and frozen ground, in Climate Change 2007: The Physical Science Basis-Contribution of Working Group I to the Fourth Assessment Report of the Intergovernmental Panel on Climate Change, edited by S. Solomon et al., pp. 337-383, Cambridge Univ. Press, New York.

Liston, G. E., and J. G. Winther (2005), Antarctic surface and subsurface snow and ice melt fluxes, J. Clim., 18(10), 1469-1481.

Liu, H., L. Wang, and K. C. Jezek (2006), Spatiotemporal variations of snowmelt in Antarctica derived from satellite scanning multichannel microwave radiometer and Special Sensor Microwave Imager data (19782004), J. Geophys. Res., 111, F01003, doi:10.1029/2005JF000318.

Masson, V., et al. (2000), Holocene climate variability in Antarctic based on 11 ice-core isotopic records, Quat. Res., 54(3), 348-358.

Morgan, V., and T. D. van Ommen (1997), Seasonality in late-Holocene climate from ice-core records, Holocene, 7(3), 351-354.

Moy, C. M., et al. (2002), Variability of El Nino/Southern Oscillation activity at millennial timescales during the Holocene epoch, Nature, 420(6912), 162-165.
Nye, J. F. (1963), Correction factor for accumulation measured by the thickness of the annual layers in an ice sheet, J. Glaciol., 4, 785-788.

Oerlemans, J. (2001), Glaciers and Climatic Change, 148 pp., A. A. Balkema Publishers, Brookfield, Vt.

Ohmura, A. (2001), Physical basis for the temperature-based melt-index method, J. Appl. Meteorol., 40(4), 753-761.

Parizek, B. R., and R. B. Alley (2004), Ice thickness and isostatic imbalances in the Ross Embayment, West Antarctica: Model results, Global Planet. Change, 42(1-4), 265-278.

Price, S. F., H. Conway, and E. D. Waddington (2007), Evidence for late Pleistocene thinning of Siple Dome, West Antarctica, J. Geophys. Res., 112, F03021, doi:10.1029/2006JF000725.

Raynaud, D., J. Chappellaz, C. Ritz, and P. Martinerie (1997), Air content along the Greenland Ice Core Project core: A record of surface climatic parameters and elevation in central Greenland, J. Geophys. Res., 102(C12), 26,607-26,613.

Reeh, N. (1991), Parameterization of melt rate and surface temperature on the Greenland Ice Sheet, Polarforschung, 59, 113-128.

Reeh, N., et al. (2005), An empirical firn-densification model comprising ice lenses, Ann. Glaciol., 42, 101-106.

Rowe, C. M., M. R. Anderson, T. L. Mote, and K. C. Kuivinen (1995), Indications of melt in near-surface ice-core stratigraphy: Comparisons with passive-microwave melt signals over the Greenland ice sheet, Ann. Glaciol., 21, 59-63.

Severinghaus, J. P., et al. (2003), A method for precise measurement of argon 40/36 and krypton/argon ratios in trapped air in polar ice with applications to past firn thickness and abrupt climate change in Greenland and at Siple Dome, Antarctica, Geochim. Cosmochim. Acta, 67(3), 325343.

Shipp, S. S., J. Anderson, and E. Domack (1999), Late PleistoceneHolocene retreat of the West Antarctic Ice Sheet system in the Ross Sea: Part 1-Geophysical results, Geol. Soc. Am. Bull., 111(10), 1486-1516.

Smith, S. R., and C. R. Stearns (1993), Antarctic pressure and temperature anomalies surrounding the minimum in the Southern Oscillation Index, J. Geophys. Res., 98(D7), 13,071-13,083.

Steig, E. J., D. L. Morse, E. D. Waddington, M. Stuiver, P. M. Grootes, P. A. Mayewski, M. S. Twickler, and S. I. Whitlow (2000), Wisconsinan and Holocene climate history from an ice core at Taylor Dome, western Ross Embayment, Antarctica, Geogr. Ann., Ser. A, 82(2-3), 213-235.

Stone, J. O., G. A. Balco, D. E. Sugden, M. W. Caffee, L. C. Sass III, S. G. Cowdery, and C. Siddoway (2003), Holocene deglaciation of Marie Byrd Land, West Antarctica, Science, 299(5603), 99-102.

Taylor, K. C., et al. (2004a), Dating the Siple Dome (Antarctica) ice core by manual and computer interpretation of annual layering, J. Glaciol., 50(170), 453-461.

Taylor, K. C., et al. (2004b), Abrupt climate change around $22 \mathrm{ka}$ on the Siple Coast of Antarctica, Quat. Sci. Rev., 23(1-2), 7-15.

Torinesi, O., M. Fily, and C. Genthon (2003), Variability and trends of the summer melt period of Antarctic ice margins since 1980 from microwave sensors, J. Clim., 16(7), 1047-1060.

Voigt, D. E., R. B. Alley, S. Anandakrishnan, and M. K. Spencer (1993), Ice-core insights into the flow and shut-down of Ice Stream C, West Antarctica, Ann. Glaciol., 37, 123-128.

Waddington, E. D., H. Conway, E. J. Steig, R. B. Alley, E. J. Brook, K. C. Taylor, and J. W. C. White (2005), Decoding the dipstick: Thickness of Siple Dome, West Antarctica, at the Last Glacial Maximum, Geology, 33(4), 281-284.

Zwally, H. J., and S. Fiegles (1994), Extent and duration of Antarctic surface melting, J. Glaciol., 40, 463-476.

Zwally, H. J., C. L. Parkinson, and J. C. Comiso (1983), Variability of Antarctic sea ice and changes in carbon dioxide, Science, 220(4601), $1005-1012$.

R. B. Alley, Department of Geosciences and Environment Institute, Pennsylvania State University, University Park, PA 16802, USA.

S. B. Das, Department of Geology and Geophysics, Woods Hole Oceanographic Institution, Woods Hole, MA 02543, USA. (sdas@whoi. edu) 